International Journal of Social and Educational Sciences Volume 2, Issue 4 December 2015

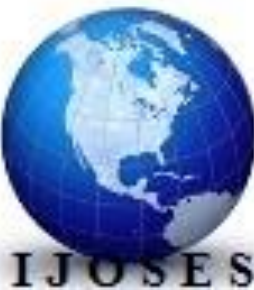

Uluslararası Sosyal ve Ĕ̈itim

Bilimleri Dergisi

Cilt 2, Sayı 4

Aralık 2015

ISSN: $2148-8673$

\title{
ORTAÇAĞDA ORIJjINAL BİR SIYYASI YAPI: GÜÇLÜ VE NÜFUZLU HER EMİR SULTAN OLUR
}

\author{
AN ORIGINAL POLITICAL STRUCTURE IN THE MIDDLE AGE: POWERFUL AND \\ INFLUENTIAL EACH COMMANDER HAS BECOME SULTAN
}

Ahmet SAĞLAM*

\section{Özet}

Ortaçağ Türk-İslam devletleri hanedanlar tarafından yönetilirken Memlûk Türk Devleti'nde farklı bir siyasi yapı karşımıza çıkar. Haçlıların işgali sonrasında Moğolların istilâsına maruz kalan Türk-İslam coğrafyasında XIII. yüzyılda yaşanan siyasi ve askeri gelişmeler güçlü ve nüfuzlu emirlerin Memlûk Türk Devleti'nde sultan olmasını sağlamış ve bu sultanlar Mısır, Suriye ve Hicaz bölgesini üç asra yakın yönetmişlerdir. Zaman zaman irsiyet bağlılığıyla sultanlar tahta otursalar da devlete hükmetmeleri hanedan mensubu olmalarından ziyade güçleri, nüfuzları ve idaredeki ustalıklarıyla alakalıdır. Devletin kuruluşundan sükûtuna değin (648-923/1250-1517) değişmeyen bu teamüller döneme ve bölgeye mahsus bir saltanat yapısını doğurmuştur. Çalışmamızda Memlûk Türk Devleti'nin saltanat yapısının şekillenme süreci olan ilk yüzyılında yaşanan saltanat değişiklikleri bağlamında devletin saltanat yapısını ortaya koymaya çalışacağız.

Anahtar Kelimeler: Memlûkler, Saltanat, Güç, Nüfuz

\section{Abstract}

Medieval Turkish-Islamic states were being governed by dynasties, we face a different political structure of the Mamluk Turkish State. The political and military developments in the XIII. century in the Turkish-Islamic geography exposed to invasion of Mongol after invasion of the Crusaders, ensured the powerful and influential commander to be sultan in the Mamluk Turkish State. And those sultans have almost ruled Egypt, Syria and Hijaz region for three centuries. Even if they ascended the throne with their hereditary from time to time, it was related with their mastery, power and influence in the management of the state rather than being member of the dynasty. These practices not changing from establishing of the state to the end of the state have formed a reign of structure peculiar to the period and region. We will reveal the state's reign structure in terms of changes of reign taking place in the first century of Mamluk State's reign structure formation.

Key Words: Mamluks, Reign, Power, Influence

* (Yrd Doç. Dr.) Artvin-Çoruh Üniversitesi Fen-Edebiyat Fakültesi Tarih Bölümü,
ahmetsaglam352@gmail.com




\section{ORTAÇAĞDA ORİJINAL BİR SIYYASİ YAPI: GÜÇLÜ VE NÜFUZLU HER EMİR SULTAN OLUR}

\section{Giriş}

Devletlerin bir canlı gibi doğduklarını, geliştiklerini ve zamanı geldiğinde de yaşamlarının sona erdiğini ifade eden İbn Haldun, kavminin ve akrabalarının yardımıyla devlet kuran sultanların, devletin kuruluş aşaması sonrasında yakınlarının tahakkümünden kurtulmak için başka bir unsura yani kendi neslinden olmayan yardımcılara ihtiyaç duyduğunu ${ }^{1}$ belirtir. Ortaçağ İslam devletlerinin en önemli hususuna işaret eden İbn Haldun, bu sözleriyle sultanın devlete hâkim olması için kudret ve şevketini dayandıracağı asabiyet erbabına olan ihtiyacını vurgulamaktadır. $\mathrm{Bu}$ çerçevede geçmiş dönemlere baktığımızda hilafetin saltanata dönüşmesiyle başlayan iktidar mücadelesinde I. Emevi halifesi Muaviye (661-680) asaletini ve gücünü aldığı Ümeyye kabilesinden başka siyasi otoritesinde en fazla dayandığı güç Kelb kabilesidir. ${ }^{2}$ Halife Muaviye'nin özel muhafız birliği kurduğu Beni Kelb kabilesi hem iktidarını güçlendirmiş hem de bir hanedan oluşumunu sağlayan amillerden biri olmuştur. ${ }^{3}$ Yine Emeviler sonrası zihniyet değişimi anlayışıyla ${ }^{4}$ iktidarı ele geçiren Abbasiler, Emevilerin dışladığı toplumların da şüphesiz desteğini almışlardır. Ancak iktidara yürümelerinde pay sahibi olan unsurlardan birçoğunu dişlamışlar ${ }^{5}$ özellikle İanlı bir aile olan Bermekilerin ${ }^{6}$ zamanla devlette söz sahibi olmasına göz yummuşlardır. Hatta devlete hâkim olmak isteyen grupların çekişmesi Halife Harun Reşit'in oğulları Emin ile Memun arasındaki taht mücadelesinde ayyuka çıkmıştır. Bu çekişme bir yerde "Araplar mi Íranlılar mı devlete egemen olacak?" mücadelesine dönüşmüştür. ${ }^{7}$ İranlıların desteği ile iktidarda kalan Me'mun (812-833) sonrasında Mu'tasım (833-842)'ın en büyük destekçileri bu kez Türkler olmuştur. ${ }^{8}$

Müslümanların İran'1 fethetmesiyle birlikte Türkler, İslam ordularında asker olarak istihdam edilir. Üstün askerî özellikleri ve kahramanlıklarıyla Türkler ${ }^{9}$ kısa sürede

\footnotetext{
${ }^{1}$ İbn Haldun, Mukaddime, I-III, (Ter. Zakir Kadiri Ugan) MEB Yay. İstanbul 1991, c. I, s. 460.

${ }^{2}$ Halife Muaviye (661-680) Ümeyye ailesinden sonra özel olarak desteğini aldığı Kelb kabilesi sayesinde siyasi nüfuzunu artırmıştır. Hilafetin saltanata dönüştüğü istihlaf meselesi (halefini tayin etme) yani veliaht olarak gösterdiği oğlu Yezid, Kelb kabilesinden evlendiği hanımından doğmuştur. Nadir Özkuyumcu, “Kelb", DİA, c. XXV, Ankara 2002, s. 203-204.

${ }^{3}$ Muaviye'nin Kelb kabilesine mensup hanımı Meysun'dur. İrfan Aycan, “Saltanata Giden Yolda Muaviye b. Ebî Süfyan", İslâmî Araştırmalar Dergisi, Cilt:4; S:2, Nisan 1990, s. 136.

${ }^{4}$ Emeviler asabiyet mantığı ile hareket etmişler Emevî ve Kelb kabilesi dışında kalan Araplar dâhil tüm unsurlara mesafeli davranmışlardır. Özellikle yeni Müslüman olan İranlı ve Orta Asya menşeli toplumlar Abbasilerin iktidar olmasında haklı bir paya sahiptirler.

${ }^{5}$ Abbasilerin iktidar olmasında önemli katkıları olan Abdullah b. Ali ve Ebu Müslim Horasânî Halife Mansur (754-775) tarafından tertip edilen siyasi entrikalarla öldürülmüşlerdir. Hakkı Dursun Yıldız, "Illk Dönem Abbasi Halifeleri", DGBİT, İstanbul 1992, c. III, s. 64-69. Bu durum İbn Haldun'un yukarıda ifade ettiği yakınlarının tahakkümünden kurtulmayı amaçlayan çabaya ideal bir örnektir.

${ }^{6}$ Bermekiler hakkında bkz. Hakkı Dursun Yıldız, "Bermekiler", DIA, c. V, İstanbul 1992, s. 517-520.

${ }^{7}$ Hakkı Dursun Yıldız, "Türklerin Müslüman Olmaları", DGBİT, İstanbul 1992, c. VI, s. 20.

${ }^{8}$ Ebülfez Elçibey, Tolunoğulları (868-905), (Haz. Fazil Gezenferoğlu), İstanbul 1997, s. 42-43; Hakkı Dursun Yıldız, İslamiyet ve Türkler, İstanbul 2000, s. 109.

${ }^{9}$ Türklerin üstün askeri kabiliyet ve ahlaki özellikleri için dönemin çağdaşı Cahiz müşahedelerini anlatır. Bu konuda bkz. Ramazan Şeşen, El-Cahiz ve Türklerin Faziletleri, İstanbul 2002.
} 
halifelerin gözde birliklerinde yer alırlar. Abbasi halifesi Mu'tasım'ın hilafet dönemi (833-842) Türklerin memlûk adı altında askeri hizmetlerde yoğun olarak istihdam edildiği bir devirdir. ${ }^{10}$ Ordu içinde diğer gruplardan tecrit edilerek Türklerden müteşekkil birliklerin oluşumu zamanla Türk asıllı komutanların üst düzey askeri mevkilere yükselmesini sağlamış, bu durum Türk memlûklerinin ${ }^{11}$ nüfuzlarını artırmış ve giderek güçlenmişlerdir. Daha sonra da "Sâmerrâ Devri" olarak adlandırılan "Abbasî Devleti'nde Türkler'in iktidar devresi"12 başkent ve eyaletlerde Türk asıllı memlûklerin idarî, askerî makamlarda söz sahibi oldukları bir dönem olmuştur. ${ }^{13}$ Merkezi otoritenin zayıflamasına paralel eyalet valilerinin memlûk edinmesi zamanla başkentin otoritesini sarsmaya dolayısıyla da başkentten uzak bölgelerdeki valilerin bağımsız hareket etmelerine yol açar. Nitekim Mısır'da Tolunoğulları (868-905) devletini kuran Tolunoğlu Ahmed (868-884) ${ }^{14}$ ile İhşîdiler (935-969) devletinin kurucusu Muhammed b. Togaç (935-946) ${ }^{15}$ Abbasiler döneminde ilk uygulamalarını gördüğümüz memlûk kökenli askerler iken devlet kuran emirler olmuşlardır. ${ }^{16}$ Özellikle Tolunoğulları dönemi (868-905) Nil'den Fırat'a Misır ve Suriye ${ }^{17}$ tarihinin geleceğini etkileyen, bölgenin kaderinde önemli izler taşıyan bir devlet olarak hatırlanır. Gerçekten de İhşidiler, Fatımiler, Eyyûbiler ve Memlûkler dönemlerinde Suriye coğrafyası Mısır'a bağlı bir merkez olarak varlığını idame ettirmiş, Bereketli Hilal'in parçası olmuştur. Misır, Türklerin kurduğu bu devletler sayesinde Firavunlar döneminden beri ilk kez yerinden yönetilmiş, Misır'ın bolluk ve bereketi Misırlıların istifadesine

\footnotetext{
10 İbn Haldun, a.g.e., c. I, s. 395; Elçibey, a.g.e., s. 40; Yıldız, “Türklerin Müslüman Olmaları”, s. 17-27; a. mlf. , Islamiyet ve Türkler, s. 107-108.

11 Memlûkler ile ilgili malumat verileceğinden kısaca şunu aktaralım ki, bu askerler halifelerin özel birliklerinde istihdam edilen askerlerdir. Bu konuyla ilgili bkz. Mehmet Nadir Özdemir, “Abbasi Halifesi Mu'tasım'ın Ordusunda Bulunan Türklerin “Köle” Olup Olmadığı Meselesi”, Selçuk Üniversitesi, Türkiyat Araştırmaları Dergisi, Sayı:18, (2005), s. 211-230.

12 Türkler için inşa edildiğine inanılan bu şehir aynı zamanda Mutasım döneminde Abbasiler devletinin başkenti olmuştur. Halife Mutasım Türkler sayesinde hilafet makamını güçlendirirken aynı zamanda Türklerin devlet içinde nüfuzlarının artmasını sağlamıştır. Elçibey, a.g.e., s. 42-43; Yıldız, Islamiyet ve Türkler, s. 109.

${ }_{13}$ Kopraman, "Misır Memlûkleri”, DGBİT, İstanbul 1992, c. VI, s. 434; Süleyman Kızıltoprak, "Memlûk Sistemi", Türkler, Ankara 2002, c. V, s. 322-323.

${ }^{14}$ Kazım Yaşar Kopraman, “Tolunoğulları”, DGBİT, İstanbul 1992, c. VI, s. 55-81; Nadir Özkuyumcu, “Tolunoğulları", Türkler, Ankara 2002, c. V, s. 16.

${ }^{15}$ Kazım Yaşar Kopraman, "İhşidiler", DGBIT, c. VI, s. 194-206; Nadir Özkuyumcu, "İhşîdiler", Türkler, Ankara 2002, c. V, s. 42.

16 Detaylı bilgi için bkz. Yıldız, İslamiyet ve Türkler, s. 69-203; Kopraman, "Mısır Memlûkleri", s. 435; Kiziltoprak, a.g.m., s. 322.

17 Memlûk kaynaklarında geçen Bilâdü'ş-Şam ile kastedilen Suriye coğrafyasıdır ki, günümüzde birbirinden bağımsız devletlerin (Filistin-İsrail-Ürdün-Lübnan-Suriye) kurulduğu bu coğrafya Kalkaşendî'nin ifadesiyle, Filistin, Ürdün, Dımaşk, Humus ve Kınnesrin adlı beş bölgeden oluşmaktadır. Kalkaşendî, Ebü'l-Abbas Şihabüddin Ahmed b. Ali Kalkaşendî (ö. 821/1418), es-Subhu'l-A'şâ fî Sinâati'lİnşâ, I-XIV, (Thk. Muhammed Hüseyin Şemseddin), Beyrut 1987, c. IV, s. 88-90. Günümüz Suriye, İsrail, Filistin, Ürdün ve Lübnan toprakları tarihteki Suriye coğrafyasının karşılığıdır.
} 


\section{ORTAÇAĞDA ORİJINAL BİR SIYYASİ YAPI: GÜÇLÜ VE NÜFUZLU HER EMİR SULTAN OLUR}

sunulmuştur. ${ }^{18}$ Tolunoğullarından Memlûk Tür Devleti'ne değin Misır'da yoğun olarak memlûk istihdamı sürdürülmüştür. ${ }^{19}$ Devlet yöneticileri desteğini her zaman arkalarında hissedecekleri kendilerine sadakatle bağlı bir kitlenin varlığını tesis ettikleri gibi kendileriyle beraber devlete egemen olacak bir kitlenin varlığını da sağlamışlardır.

Ortaçağın en büyük siyasi ve askeri gelişmesi olan Moğol istilâları Abbasiler başta olmak üzere hanedanlar tarafından yönetilen birçok Ortaçağ Türk-İslam devletinin sonunu getirmiştir. Yine bu istilâlar neticesinde memlûk sistemi içinden yetişen askerler kendi irade ve idarelerinde bağımsız bir devlet kurmuşlar ve Türk-İslam dünyasında oluşan siyasi boşluğu doldurmuşlardır. Memlûk kökenli askerler Moğolların Deşt-i Kıpçak ${ }^{20}$ bölgesine yaptıkları istilalar ${ }^{21}$ neticesinde esir pazarlarında bolca bulunan çoğu çocuk yaştaki Kıpçaklar esir tacirleri tarafından Mısır'a getirilmişlerdir. ${ }^{22}$ Dolayısıyla Moğolların topraklarını işgal ettiği Kıpçak Türkleri ilk dönem memlûkler içinde yoğun olarak bulunmuşlardır. Ancak esaretten başka kıtlık, açlık, kuraklık ve hastalık gibi doğal afet durumları, ailelerin zorunlu ${ }^{23}$ ya da çocuklarını satmalarının adet olduğu durumlar memlûk sisteminin önemli insan

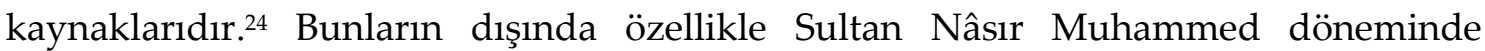

\footnotetext{
${ }^{18}$ Özkuyumcu, “Tolunoğulları”, s. 34.

${ }^{19}$ Altan Çetin, , Memlük Devletinde Askeri Teşkilat, Eren Yayıncllık, İstanbul 2007, s. 48-52.

${ }^{20}$ Kuman-Kıpçak ülkesi beş kısma ayrılır ki, Orta Asya, Yayık-Volga, Don-Donetz, Aşağı Dinyeper ve Tuna'dır. XIII. Yüzyıl Moğol istilası ile parçalanmalar, zorlaşan hayat şartları, hastalıklar ve kıtlıklar ile mücadeleler; bölge insanını, yöreye özgü bir gelenek olan sıhhatli gürbüz çocukların para karşılı̆̆1 satımını zorunlu kılmıştır. Ömerî, Ebü'l-Abbas Şehabeddin Ahmed b. Yahyâ İbn Fazlullah el-Ömerî (ö. 749/1349), Mesâlikü'l-Ebsâr fí Memâliki'l-Emsâr, I-XXVII, (Thk. Kamil Selman el-Cebûrî), Beyrut 2010, c. III, s. 150. Kıpçak çölü veya Kıpçak bozkırı anlamına gelen Deşt-i Kıpçak, Kafkas Dağları'nın kuzeyinde, Dinyester ile İrtiş ırmakları arasındaki bölgenin tarihsel adıdır. Ferit Develioğlu, Osmanlıca-Türkçe Ansiklopedik Lûgat, Ankara 2006, s. 180. İslam kaynaklarında Doğu Avrupa- Batı Sibirya bozkır bölgeleri yani Kuman-Kıpçak sahası Deşt-i Kıpçak (Kıpçak Bozkııı) olarak zikredilmiştir. İbrahim Kafesoğlu, Türk Milli Kültürü, Ötügen Neşriyat, İstanbul 2006, s. 188-193.

${ }^{21}$ İbnü'1-Esir, El Kâmil Fi't-Tarih Tercümesi, Bahar Yayınları, İstanbul 1985, c. XII, s. 312-315.

${ }^{22}$ Nüveyri, Ebu'l-Abbas Şihabüddîn Ahmed b. Abdülvehhâb b. Muhammed el-Bekrî et-Teymî el-Kureşî en-Nüveyrî (ö. 733/1333), Nihâyetü'l-Ereb fi Fünûni'l-Edeb, (Thk. Dr. Necip Mustafa Fevvaz, Dr. Hikmet Keşlî Fevvaz), Beyrut 2004, c. XXIX, s. 268-269.

${ }^{23}$ Çalışma dönemimizin çă̆daşı olan Ömerî, eserinde Havarizm ve Kıpçak bölgesini anlatırken söz konusu bölgede yaygın olan çocuk alım-satımları hakkında detaylı bilgi verir. Ravilerin isimlerini vererek naklettiği bilgilerde, söz konusu Kıpçak ülkesinde yöneticilerin tebaasından birine kızdığında malını gasbedip çocuklarını alıp sattığını, yine hırsızlığın meşru olup çalınan çocukların satıldığını ayrıca vergisini ödeyemeyen ailelerin çocuklarını satarak vergilerini ödeme yoluna gittiklerinden bahseder. Ömerî, 738 Recep ayında (Şubat 1338) Kıpçak Bozkırında dolaşıp Akça Kirman (Akkirman) ve Bulgar ülkesine geçen tacir eş-Şerif Şemseddin Muhammed el-Huseyni el-Kerbelâi'nin kendisine anlattı̆̆ bilgiyi paylaşarak, seyahati sırasında maiyetinde getirdiği memlûkleri ve cariyeleri ihtiyaçlarından dolayı satan anne ve babalarından satın aldığını naklediyor. Ömerî, a.g.e., c. III, s. 149-150.

${ }^{24}$ Kalkaşendî, Maişet darlığından dolayı evlatlarını sattıklarından söz ederek gayri müslim olan özellikle Türk cinsinin cesareti, şecaati, vefakârllğının yanında çehresi güzel ve zarif insanlar olduklarından bahseder. Kalkaşendî, a.g.e., c. IV, s. 458.
} 
olduğu gibi aileler çocuklarını fahiş ücretler karşılığında ileride onların yaşayacağı şaşalı günlerin hayali ve kendilerinin de fakirlikten kurtulacakları ümidiyle gönüllü olarak çocuklarını satmışlardır. ${ }^{25}$ Nadir de olsa tamamen hür olan kimseler de memlûk sinıfına katılmıştır. ${ }^{26}$

Memlûkler anayurtlarından memlûk tacirleri aracılığılya getirildikleri Kahire'de

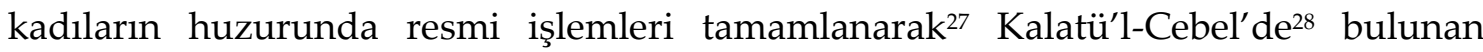
tıbaklara $^{29}$ kendi cinslerinin yanına yerleştirilirler. Büluğ yaşına kadar temel İslami ilimlerin tedris edildiği sonrasında da askerlik sanatının talim edildiği okullar olan tıbaklar memlûk kimliğinin ve grup dayanışmasının kazandırıldığı önemli bir

${ }^{25}$ Makrizi bu konuyla ilgili şu ifadeleri kullanır; "Memlûk sultanı için, kişi başına 100 bin dirhem (5 000 dinar) ödeyen tacire bir baba karşı koyamaz, oğlunu satardı". Makrizi, Ebü'l-Abbas Takıyyüddin Ahmed b. Ali b. Abdülkadir Makrizi (ö. 845/1442), Kitabü'l-Mevâiz ve'l-ïtibâr fi Zikri'l-Hıtat ve'l-Âsâr, I-II, Beyrut t. y. Dâru Sâdır, c. II, s. 214.

${ }^{26}$ Örneğin Nâsır Muhammed için Özbek Han'dan gelen gelin alayında görevli Kavsûn, hür bir insan iken resmi işlemler sonrası tacirlikten Nâsır Muhammed'in memlûkleri arasına katılmıştır. Hür bir insan olan Kavsun Nâsır Muhammed'in dikkatini çekmiş ve sekiz bin dirhem ödeyerek memlûkleri arasına girmiştir. Yine tıbak'a göndermeden emirlik tevcih ettiği Kavsun sultanın damadı olarak gözde emirlerinden olmuştur. Makrizi, Hıtat, c. II, s. 307-308. Kavsun (ö. 742/1341)'un hayatı hakkında bkz. Safedî, Salahaddin Halil bin İzzeddin Aybek es-Safedî (ö. 762/1363), A'yânü'l-Asr ve A'vânü'n-Nasr, I-VI, (Thk. Ali Ebû Zeyd, Mahmûd Salim Muhammed, Nebil Ebû Amse, Muhammed Mev'id), Dımaşk 1998/1418, c. IV, s. 136-140; İbn Tağriberdi, Ebü'l-Mehasin Cemalüddin Yusuf İbn Tağriberdi (ö. 874/1470), el-Menhelü's-Sâfí ve'lMüstevfí ba'de'l-Vâfí, I-XIII, (Thk. M. Muhammed Emin, Said Abdülfettah Âşûr), Kahire 1984/1405, c. IX, s. 107-110; J. Van Steenbergen, "The Amir Qawsun: Statesman or Courtier? (720-741 AH/1320-1341 AD)" In Egypt and Syria in the Fatımid, Ayyubid and Mamluk Eras, III, ED. U. Vermeulen and J. Van Steenbergen, 2001, s. 449-466.

${ }^{27}$ Kadıların onayı ve tanıklıklarıyla gerçekleştirilen bu işlemler tamamen belgelendirmeye dayalıdır. Savaşlarda esir düşmedikleri müddetçe hür insanlar asla bu sisteme dâhil olmazlar. Zoraki elde tutulanlar hürriyetlerini ispatladıkları takdirde serbest kaldıkları gibi gâsıplar cezalandırılırlar. Makrizi, Hıtat, c. I, s. 374; c. II, s. 92, 213-214.

${ }^{28} \mathrm{Kal}^{\prime}$ atü'l-Cebel, sadece sultanın ve ailesinin yaşadığ 1 bir saray ve sultanın dairelerinin bulunduğu bir yer değil aynı zamanda memlûklerin yetiştirildiği kışlalar, tablhâne, taşthâne, üst düzey ümeranın köşkleri, çarşılar, meydanlar, camiler, hamamlar ve medreseleri de içine alan büyük bir külliye, saray-kale konumunda bir yerdir. Selahaddin Eyyûbi (567-589/1171-1193) tarafından inşasına başlanan ve oğlu Seyfeddin Melik Adil (596-615/1200-1218) döneminde tamamlanan saray-kale Kahire'deki Mukattam dağının bir tepesinin üzerindedir. Eyyûbiler ve Memlûkler döneminde sultanların ikamet yeri olan Kal'atü'l-Cebel için bkz. Ömerî, a.g.e., c. III, s. 330-334; Kalkaşendî, a.g.e., c. III, s. 372-379; Halil b. Şahin ezZahiri (ö. 873/1468), Zübdetü Keşfi'l-Memâlik fi Beyanii't-Turuk ve'l-Mesâlik, (Thk. Halil Mansur), Beyrut 1997/1417, s. 23-24; Makrizi, Hitat, c. II, s. 201-206; Fuad Seyyid Eymen, "Kahire", DİA, c. XXIV, Ankara 2001, s. 174; Ahmet Ali Bayhan, "Kahire Kalesi", Güzel Sanatlar Enstitüsü Dergisi, Sayı:10, Erzurum 2003, s. 7-41.

${ }^{29}$ Tibâklar (=Atbâk, tekili:tabaka) Sultan Baybars tarafından Kal'atü'l-Cebel'de inşa edilen memlûklerin küttâbiye ve fürûsiyye eğitimi aldıkları okullar olup daha sonra Muhammed b. Kalavun tarafından genişletilmiştir. Makrizi, Hitat, c. II, s. 92, 213-21; David Ayalon, "Memlûk Devletinde Kölelik Sistemi", (Çev. Samira Kortantamer), Tarih Incelemeleri Dergisi, IV (1989), s. 223; Cengiz Kallek, "Tabaka", DİA, c. XXXIX, Ankara 2010, s. 288. 


\section{ORTAÇAĞDA ORİJINAL BİR SIYYASİ YAPI: GÜÇLÜ VE NÜFUZLU HER EMİR SULTAN OLUR}

merkezdir. ${ }^{30}$ Burada hiyerarşik idari bir yapıda görev yapan hadımlar ${ }^{31}$ gözetiminde çok sıkı eğitimden geçirilirler. Başarılı bir şekilde eğitimlerini tamamladıktan sonra azat edilerek rütbesiz bir asker hüviyetinde memlûkü oldukları emirin ya da sultanın hizmetine girerler. ${ }^{32}$ Memlûklerin Kahire'ye intikali her yıl düzenli olarak bu işle görevli tacirler aracılığı ile sağlanır. Her sultan ve her emir her zaman taze kanlarla memlûk oligarşisini kuvvetli tutmaya çalışmıştır. Aslında tahta yeni oturan sultanın iktidardaki gücü ve nüfuzu kendi memlûklerinin askeri ve siyasi kadrolarda istihdam edilmesiyle sağlanan bir güç ile alakalıdır. Sultanın gücü siyasi kişiliği kadar memlûk oligarşisinin devlete hâkimiyeti ile alakalıdır.

Devletin saltanat yapısına geçmeden önce şunu hatırlatalım ki, memlûk sözcügü Abbasilerin ilk dönemlerinden Misır'da kendi irade ve idarelerinde devlet kurdukları Memlûk Türk Devleti'ne değin siyasi ve hukuki anlamda yeni anlamlar kazanmıştır. Sözcüğünün kaynağı olarak İslam hukukuna baktığımızda gündelik işlerde çalışan köleler ve hizmetçiler için kullanılan ve "teslimiyet ve itaat" anlamina gelen $a b d^{33}$ sözcüğü köle anlamında en yaygın kullanılan bir sözcüktür. Dönemin cari hukuku olan İslam hukukunda kölelikle ilgili hükümlerin memlûkler için geçerli olmaması yani İslam hukukunun hürler hakkındaki hukukunun memlûkler için uygulanmış olması da hukuken göstermektedir ki bu askerler köle muamelesi görmemiş hatta çalışma konumuz olan Memlûk Devleti döneminde toplumun elit bir sınıfı olarak hayatlarını idame ettirmişlerdir. Memlûk kökenli askerler ortaçağ İslam devletlerinde sultanın ve emirlerin hizmetinde askerler iken Memlûk Türk Devleti'nde devletin sahibi olan seçkin bir sınıf olmuşlardır.

30 Müslüman yapılıp sünnet edilen ve büluğ yaşına kadar dini eğitim alan bir memlûk tıbak'a yerleştirilmeden önce Türkçe bir isim alır. Tıbâk'ta acemi olarak geldiğinde "ini" ismiyle sorumlu olduğu bir "ă̆a"nın kontrolünde hareket eder. Aynı efendinin memlûkleri "hûşdâşiye" adıyla zikredilir ki (günümüzde aynı yıllarda askeri okullara ve polis kolejlerine girenlerin yanı sıra aynı yıllarda askerlik yapanların tertip-devre kelimelerini kullanmaları gibi) ilerde görev aldıklarında birbirlerini kollayan bu insanlar arasında grup dayanışması söz konusudur. Bir aile ortamı için gerekli kavramların ihdas edilip birbirlerine kaynaşmaları için yarışların düzenlendiği, asabiyet bağlarının aşılandığı tıbaklarda fürusiyye yani bir süvari için gerekli askeri eğitimler verilir. Bu eğitimler ferdi olmalarının yanı sıra kabak, çevgân (top oyunu), atıcılık gibi toplu yarışlar tertip edilir. Ayrıca azat oluncaya kadar evlenmelerine izin verilmez. Çetin, a.g.e., s. 81-92.

31 Tavâşî adındaki hadım edilmiş eğitmenlerdir. Ayalon, “Kölelik Sistemi”, s. 227-228; Çetin, a.g.e., s. 81-82.

32 Makrizi bu konuyla ilgili şu bilgileri verir; "Devletin ilk döneminde memlûkler, anavatanlarından MısırKahire'ye küçük çocukken getirilirlerdi. Genç memlûk kendi cinsinden yani ırkından olanlara tahsis edilmiş bir tabaka'ya yerleştirilirdi, çocuk yaştaki memlûk bir hadıma teslim edilerek Kur'an-ı Kerim'den gerekli olan bilgileri öğrenmeye başlardı. Her grup öğrenci için Kur'an-ı, yazmayı, şeriatın temellerini ve duaları öğretmek amacıyla her gün gelen din hocası veya fakih vardı. Fakîh yeni yetme memlûklere İslam dininin temel bilimlerini tekrar ederek öğretirdi. Memlûk yetişkin çă̆ına gelince silah kullanma sanatını, yay ve mızrak kullanmasın öğrenmiş olurdu". Makrizi, Hıtat, c. II, s. 213-214; a.mlf., Kitâbü's-Sülûkli-Ma'rifeti Düveli'l-Mülûk, I-IV, (Thk. Muhammed Mustafa Ziyade-Said Abdülfettah Âşûr), Kahire 1934, 1958, c. II, s. 524-525; İbn Tağriberdi, Ebü'l-Mehasin Cemalüddin Yusuf İbn Tağriberdi (ö. 874/1470), en-Nücûmü'z-Zâhire fî Mülûki Mısr ve'l-Kahire, I-XVI, (Thk. Muhammed Hüseyn Şemseddin), Dâru'l-Kütübi'l-İlmiye, Beyrut 1992/1413, c. IX, s. 127-128.

${ }^{33}$ Muhammed Hamidullah, "Abd”, DİA, c. I, İstanbul 1988, s. 57. 


\section{Memlûk Türk Devleti'nde Saltanat Yapısı}

Bahrî Memlûkler ${ }^{34}$ olarak isimlendirilen Kıpçak Türkleri idaresindeki Memlûk Türk Devleti (ed-Devletü't-Türkiye ${ }^{35}$ )'nin ilk devri devletin saltanat yapısının da şekillendiği bir dönem olmuştur. Bu dönemde memlûk asıllı emirler saltanat makamını ya gasp ederek ele geçirmişler ya da saltanat veraset yoluyla el değiştirmiştir. Tahta oturan memlûk kökenli emirler uzak diyarlardan gelmiş türlü sebeplerle yerlerinden yurtlarından kopmuş ve sıkıntılı bir çocukluk evresi geçirmiş insanlardır. Bu insanlar yönetici sınıfının sahip olduğu nimetlerden tatma hırsıyla daha tıbaklarda yani okullarda iken mücadeleye girişirler. Bu mücadele önce kendini iyi bir asker olarak ispatlama çabasıdır. Cesaretli ve dirayetli her memlûk hiyerarşi basamaklarını hızla tırmanarak zamanla da siyaset aklını kullanarak devletin başına geçme fırsatını yakalar. Bu durum aslında çok ince bir çizgide kılı kırk yararcasına devam eden çetrefilli yollardan geçerek elde edilen bir başarı öyküsüdür. İktidar yolunun bir diğer

\footnotetext{
${ }^{34}$ Memlûkler olarak günümüzde isimlendirilen devletin kurucuları yani memlûk kökenli askerler Eyyûbi sultanı Salih Necmeddin Eyyûb (1240-1249) tarafından özel olarak Nil nehrinin ortasında bulunan Ravza isimli adaya yerleştirilmişler ve burada eğitim almışlardır. Ravza adasının içinde bulunduğu Nil nehrine Araplar arasında Nil Denizi (Bahru'n-Nîl) denilmesinden hareketle el-Memâlikü'l-Bahriyye yani Bahrî Memlûkler diye isimlendirilmişlerdir. Makrizi, Mısır tarihi üzerine yaptığı tasnifinde Eyyûbiler dönemi, Bahriyye dönemi ve Bahrîlerin evlatlarının memlûklerinin dönemi şeklinde son dönemi üç kısımda ele alır. Makrizi tarafından yapılan bu tasnif için bakınız. Makrizi, Hitat, c. II, s. 232. Bir sonraki dipnotta ele alacağımız üzere devlet Türkiye Devleti olarak başta Makrizi'nin eserleri olmak üzere dönemin çağdaş ve muahhar kaynaklarında geçmektedir.

35 Memlükler Devleti tarihini anlatmaya başlayan dönemin müellifleri bu devletin adını eserlerinde Devletü't-Türk (=Türk Devleti) ya da ed-Devletü't-Türkiyye (=Türkiye Devleti) diye tanımlarlar. Baybars elMansûrî (ö. 725/1325), Zübdetü'l-Fikre fî Târîhi'l-Hicre (Thk. D. S. Richards), Beyrut Das Arabische Buch Berlin, 1998/1419, s.1; İbn Devâdârî, Ebû Bekr b. Abdullah b. Aybek İbnü'd-Devadari (ö. 736/1336), Kenzü'd-Dürer ve Câmiü'l-Gurer I-IX, (Thk. Ulrich Haarmann), Kahire 1971, c. VIII, s. 12; Nüveyri, Ebu'lAbbas Şihabüddîn Ahmed b. Abdülvehhâb b. Muhammed el-Bekrî et-Teymî el-Kureşî en-Nüveyri (ö.733/1333), Nihâyetü'l-Ereb fî Fünûni'l-Edeb, I-XXXI (Thk. Dr. Necip Mustafa Fevvaz, Dr. Hikmet Keşlî Fevvaz), Beyrut 2004, c. XXIX, s. 267; İbn Kesir, Ebü'l-Fidâ İmadüddin İsmail b. Şihabüddîn Ömer b. Kesîr b. Dav' b. Kesir (ö. 774/1373), el-Bidâye ve'n-Nihâye, I-XXI, (Thk. Abdullah b. Abdülmuhsin et-Türkî), Cîze 1998/1419, c. XVII, s. 308; İbn Haldun, Ebu Zeyd Veliyyüddin Abdurrahman b. Muhammed İbn Haldun (ö. 808/1406), Kitâbü'l-İber ve Dîvanü'l-Mübtedâ ve'l-Haber fî Eyyâmi'l-Arab ve'l-Berber ve men Âserehüm min zevi's-Sultâni'l-Ekber, I-VIII, (Thk. Halil Şehhâde), Beyrut 1421/2001, c. V, s. 426; Kalkaşendî, a.g.e., c. IV, s. 6; Makrizi (ö.1442), Makrizi, Ebü'l-Abbas Takıyyüddin Ahmed b. Ali b. Abdülkadir Makrizi (ö. 845/1442), Kitabü'l-Mevâiz ve'l-İtibâr fi Zikri'l-Hıtat ve'l-Âsâr, I-II, Beyrut t. y. Dâru Sâdır, c. II, s. 208, 211, 215, 218, 220; İbn İyas, Ebü'l-Berekat Zeynüddin Muhammed b. Ahmed İbn İyas (ö.930/1520), Bedâiu'zZuhûr, fî̀ Vekâi'u'd-Dühûr, I-V, (Thk.Muhammed Mustafa), Kahire 1395/1975, c. I, s. 288. Ayrıca dönemin çağdaş müellifleri eserlerine ed-Devletü't-Türkiye (=Türkiye Devleti) ismini vermişlerdir. Bu konuda bkz. Baybars el-Mansûrî (ö.725/1325), et-Tuhfetü'l-Mülûkiyye fi'd-Devleti't-Türkiyye (Thk. Abdülhamid Salih Hamdân), Kahire 1987; İbn Devâdârî, (ö. 736/1336), ed-Dürretü'z-Zekiyye fî Ahbâri'd-Devleti't-Türkiyye, (Thk. Ulrich Haarmann), Kahire 1971; İbn Habib (ö.1377), Dürretü'l-Eslâk fi Devleti'l-Etrâk, Süleymaniye Ktp. Yeni Cami, Nr. :849; İbn Dokmak (ö.1407), en-Nüfhatü'l-Miskiyye fî'd-Devleti't-Türkiyye: min Kitâbi'l-Cevheri's-Semin fî Siyeri'l-Hulefâ ve'l-Mülûk ve's-Selâtîn (min sene 637 hatta sene 805 h.), (Thk. Ömer Abdüsselam Tedmuri), Beyrut 1999/1420. Ayrıca müellifi meçhul Türkiye Devleti Tarihi anlamını taşıyan bir eserin künyesi şöyledir. “Târîhu'd-Devleti't-Türkiyye (650-805/1252-1402)” [Cambridge, U.L. Ms. Qq. 147].
}

www.ijoses.com 


\section{ORTAÇAĞDA ORİJINAL BİR SIYYASİ YAPI: GÜÇLÜ VE NÜFUZLU HER EMİR SULTAN OLUR}

önemli ayağı talihin de kişinin yanında olmasıdır. İşte tüm bunlar bir araya geldiğinde genç memlûk anavatanından kilometrelerce uzakta Müslüman bir devletin başına geçme fırsatını yakalamıştır.

Memlûk Türk Devleti memlûk kökenli askerlerin yönettiği kendine özgü saltanat yapısı $^{36}$ ve merkezi bir devlet yapısı ile öne çıkmıştır. Memlûk kökenli emirlere saltanat yolunun açılması devlete hâkim bir hanedanın oluşmasını engellemiş böylece orijinal idari bir yapı doğmuştur. Bu oluşum bölgeye ve döneme mahsus gelişen siyasi ve askeri hadiselerin bir sonucudur. Halife el-Müstekfi Billah 709 yılının Şaban ayında (Ocak 1310) Nâsır Muhammed'in üçüncü kez tahta oturmak için harekete geçtiği haberini alınca tahtta bulunan Sultan Baybars el-Çaşnigîr lehine bir ahidnâme ${ }^{37}$ yayınlar. Saltanatın seleften halefe veraset yoluyla intikal etmeyeceğini bu ahidnâmesinde ${ }^{38}$ açıkça belirten halife kısaca Sultan Kalavun'un yerine oğlunun geçmesinin meşru bir dayanağı olmadığını ileri sürmektedir. Açıkçası bu ifadeler gelenek haline gelen devletin orijinal saltanat yapısını özetlemekte hem de halifenin devlet içindeki konumuna işaret etmektedir. Sultanı meşru olarak tayin eden dolayısıyla teorik açıdan devletin en üstünde yer alan halifenin saltanattaki konumuna değinerek de dönemin hilafet kurumuna açıklık getirmiş olalım.

İslam toplumunda kökü Hz. Peygamber (a.s.)'e kadar dayanan, yüzlerce yıl siyasidini bir kurum olarak Türk-İslam devletlerinin üstünde yer alan hilafet, son ikamet yeri Bağdat'ın İlhanlı hükümdarı Hülâgû tarafından 656/1258 yılında işgali sonrası hilafet kurumu hüviyetini kaybetmiştir. Ancak üç yıllık aradan sonra Memlûk Türk Devleti Sultanı Baybars, Abbasi hanedanına mensup el-Mustansır Billah Ebu'l-Kasım Ahmed'i ${ }^{39}$ 1261'de gösterişli törenlerle Kahire' de karşılamış ve kendisi burada halife

\footnotetext{
${ }^{36}$ Memlûk Devleti'nin saltanat yapısı üzerine yapılan çalışmalar hakkında bkz. P. M. Holt, "Memlük Sultanlığında Devlet Yapısı", (Ter. Samira Kontantamer), Belleten LII/202, 1988, s. 227-246; Samira Kortantamer, "Memlüklerde Devlet Yönetimi ve Bürokrasi" TíD 1984, 27-45; Amalia Levanoni, "The Mamluk Conception of The Sultanate", International Journal of Middle East Studies, Vol. 26, No. 3 (Aug. , 1994), s. 373-394.

37 Ahidnâmeler halifeler ve sultanlar adına kaleme alınan vesikalardır. Bu belge ile belge sahibine özel haklar verilir. Halife tarafından sultana verilen ahidnâme ile saltanatın meşruiyeti söz konusudur. Ayrıca Sultan halefini belirlediği bir ahidnâme yazdırır. Ömerî, et-Ta'rîf bi'l-Mustalahi'ş-Şerîf (Thk. Semîr Mahmûd Derubi), Kerek 1992/1413, s. 112.

${ }^{38}$ Halife ahidnâmede şunları kaleme almıştır; “...Ben size Allah'ın kulu el-Melikü'l-Muzaffer Rukneddin'i Mısır ve Suriye ülkelerinin idaresi için dini, becerisi ve yetkinliğinden dolayı nâibim olarak seçtim. Tüm yetkilerimi ona devrettim. Müminler adına ondan razıyım. Sultanlıktan feragatini öğrendikten sonra onu (en-Nâsır Muhammed) azlettim. Bu benim kararımdır. Dört mezhep kadısı da böyle hükmetti. Biliniz ki, Allah size rahmet etsin, saltanat irsi değildir. Sultanlık seleften halefe, büyüklerden büyüklere veraset ile intikal etmez. Ben size elMelikü'l-Muzaffer'i sultan olarak tayin ettim. Kim bana itaat ederse Allah'a itaat etmiş olur. Kim bana isyan ederse Allah'a isyan etmiş olur...".Makrizi, Sülûk, c. II, s. 65-66.

${ }^{39}$ Hayatı hakkında bkz. Süyûtî, Ebü'l-Fazl Celaleddin Abdurrahman b. Ebi Bekr b. Muhammed el-

Hudeyrî es-Süyûtî (ö. 911/1505), Târîhu'l-Hulefâ, (Thk. Muhammed Muhyiddin Abdülhamid), Kahire 1964, s. 345-346.
} 
ilan edilmiştir. ${ }^{40}$ Halife de Müslümanların başı sıfatıyla Baybars'ı sultan olarak atamış ve böylece memlûk kökenli askerlerin önderliğinde kurulan yeni siyasi oluşumun siyasi ve dini meşruiyeti tamamlanmıştır. ${ }^{41}$ Teorik olarak sultanın üstünde yer alan ancak tahta oturan sultanın cülûs töreninde seremoninin en önemli parçası olmaktan öteye geçmeyen bir konuma sahip olduğu da bir gerçektir. Şöyle ki, halife Abbasilere özgü siyah cübbeyi sultana giydiriyor, verdiği ahidnâme ile de tüm yetkilerini sultana devrederek onu bütün işlerde vekili olarak atıyordu. Böylece yeni sultan da saltanatın meşru sultanı olarak tahta oturuyordu. Haçlılar ve Moğollarla yapılan mücadelelerde elde edilen başarılar da bu seremoniye meşruiyet kazandırmış ve sürdürülen bir teamül haline gelmiştir. Yine Memlûk toplumunda dini-adli meselelerin dört Sünni mezhep (Şafi-Maliki-Hanefi-Hanbeli) kadıları tarafından yürütülmesiyle halifelik dini konulara da karışmayan hiçbir işlevi olmayan bir kurum olarak varlığını idame ettirmiştir. Özel günlerde, merasimlerde, devlet adamlarının tertip ettiği meclislerde seremoninin bir parçası olmuştur. Devlet erkânının haftada bir kez bir araya geldiği mezâlim divanında dahi yer almayan ${ }^{42}$ halife siyasete karışmayan, gözlerden uzak maaşlı bir memur gibi yaşamıştır. ${ }^{43}$

Halifenin iç siyasetteki bu etkisizliğine rağmen diş siyasette hilafet kurumu diğer Müslüman devletler üzerinde üstünlük sağlama amacıyla öne çıkarılmıştır. Kalavun, müslüman olduğunu bildiren İlhanlı hükümdarı Ahmed Teküdâr'a yine Nâsır Muhammed'in de Gazan'a halifeye itaat etmelerini istemeleri ${ }^{44}$ hilafet kurumunun diş politikada nasıl kullanıldığını göstermesi açısından önemlidir. Mekke şerifi Ebu Nümey hilafetin Kahire'de tesisinin hemen sonrasında Memlûk Türk Devleti'nin himayesine girerek tabiiyetini sunmuştur. ${ }^{45}$ Yine Yemen sultanı Müeyyed Davud, her yıl hediye adı altında gönderdiği aslında tâbi devlet statüsünün gereği olan vergileri Kahire'ye göndermeyip hutbede kendi adını Nâsır Muhammed'in isminden önce okutunca Yemen sultanına sultan ve halife adına mektuplar yazılarak tehdit edilip itaat etmesi emredilmiştir. ${ }^{46}$ Yine Hind sultanı Muhammed b. Tuğluk Memlûk

\footnotetext{
${ }^{40}$ Baybars el-Mansûrî, Zübde, s. 60-61; İbn Devâdarî, a.g.e., c. VIII, s. 73, 94; Nüveyri, a.g.e., c. XXXI, s. 13-14, 47; Makrizi, Sülûk, c. I, s. 449; Süleyman Özbek, “El-Melikü'z-Zahir Rüknü'd-Din Baybars Zamanı Dini Siyaseti", Ti், Sayı: IX, (1994), s. 289-307.

${ }^{41}$ P. M. Holt, a.g.m., s. 227.

42 Mezâlim dîvânında yer alan görevliler için bkz. Ömerî, Mesâlik, c. III, s. 292-293; Kalkaşendî, a.g.e., c. IV, s. 44; Makrizi, Hitat, c. II, s. 209.

43 Samira Kortantamer, Bahri Memlûklar'da Üst Yönetim Mensupları ve Aralarındaki İlişkiler, İzmir 1993, s. 70.

${ }^{44}$ Kalavun'un Teküdâr'a , Nâsır Muahammed'in de Gazan'a yazdı̆̆ı mektuplar için bkz. Kalkaşendî, a.g.e., c. VII, s. 236-250.

${ }^{45}$ Amalia Levanoni, “The Mamluks in Egypt and Syria: the Turkish Mamluk sultanate (648-784/1250-1382) and the Circassian Mamluk sultanate (784 923/1382 1517)" The New Cambridge History of Islam: The Western Islamic World Eleventh to Eighteenth Centuries, Edited By Maribel Fierro, Vol. II, s. 240.

${ }^{46}$ Baybars el-Mansûrî, Zübde, s. 395-396; Makrizi, Sülûk, c. II, s. 32-33; M. Cemaleddin Sürûrî, Devletü Beni Kalavun, Kahire 1947, s. 131-133. Yemen'e bizzat halifenin adıyla kaleme alınan mektup için bkz. Baybars el-Mansûrî, Zübde, s. 397-399; Kalkaşendî, a.g.e., c. VI, s. 421-426.
} 


\section{ORTAÇAĞDA ORİJINAL BİR SIYYASİ YAPI: GÜÇLÜ VE NÜFUZLU HER EMİR SULTAN OLUR}

sultanlarının tahta otururken halifeden aldığı ahidnâmeye benzer bir taklîd ${ }^{47}$ istemiştir. Hind sultanı halife el-Müstekfî Billah ile oğlu el-Hâkim Biemrillah Ahmed ile mektuplaşmış ve söz konusu taklîd kendisine yazılmıştır. ${ }^{48}$ Hilafet kurumu memlûk kökenli askerler tarafından kurulan Memlûk Türk Devleti'ne meşruiyet kazandırmış ve Memlûk siyasetinde de teorik olarak varlığını her zaman korumuştur.

\section{Memlûk Türk Devleti'nde Saltanat Yapısının Oluşumu}

İlk Memlûk sultanı İzzeddin Aybek'ten sonra veraset yoluyla Memlük tahtına on beş yaşındaki oğlu Nureddin Ali geçmiştir. Ancak Türk-İslam coğrafyasında yaşanan gelişmeler korkunç boyutlardadır. Hülâgu, Bağdat'ı ele geçirerek Abbasi hilafetine son vermiş daha sonra da Kuzey Suriye bölgesini işgal ederek Memlûk Türk Devleti'ni tehdit etmeye başlamıştır. Tehlike karşısında iç hesaplaşmaları bir tarafa bırakan emirler çocuk yaştaki sultanın kifayetsizliğini hesaba katarak tahttan indirmişler ve saltanat nâibi Kutuz'un sultanlığında anlaşmışlardır. Sultan Kutuz, Nureddin Ali'yi önce Dımaşk'ta hapsettirmiş daha sonra da Bizans'a sürgüne göndermiştir. ${ }^{49} \mathrm{Bu}$ davranışıyla da aslında Memlûk Türk Devleti'nde veraset usulünün yerleşmesinin önünü kapatmıştır.

Memlûk Türk Devleti'nin ilk dönemlerine ${ }^{50}$ baktığımızda tahtın iki seçenekten birisi ile yer değiştirdiği hatta gasp edildiği görülür. Bu durum ya siyasi bir cinayet ile sultanın öldürülmesi ya da babasının yerine tahta geçip kıdemli emirlerin kontrolünde hüküm süren kukla sultanların azli şeklinde olmuştur. Babasının yerine oğlunun sultan seçilmesi üst düzey emirlerin kendi aralarındaki iktidar ve güç dengesini gözeterek zaman kazanmaya dönük aslında geçici bir çözüm yoludur. Saltanat makamında olası rakiplerini sindiren ve şartların oluştuğuna inanan kıdemli emirlerden birisi hûşdâşlarının ${ }^{51}$ ve memlûklerinin gücünü arkasına alarak genç sultanı

\footnotetext{
47 Taklîd; sultan adına saltanat nâibi, eyalet nâibleri ve vezirler gibi üst düzey memurların tayini, azli gibi hususlarda kaleme alınan resmi yazılardır. Ömeri, Ta'rîf, s. 112. Örnek taklîdler için bkz. Ömeri, Ta'rîf, s. 115-117.

48 Sürûrî, a.g.e., s. 141.

49 İbn Devâdârî, a.g.e., c. VIII, s. 33-39; Nüveyri, a.g.e., c. XXIX, s. 294, 299-300; Makrizi, Sülûk, c. I, s. 417-418, s. 287.

50 Burada ele alınan dönem devletin kuruluşundan Sultan Nâsır Muhammed b. Kalavun'un saltanat döneminin sonlarına yani 7401341 yılına değin süre aralığıdır.

${ }^{51}$ Memlûk anavatanından Mısır'a geldikten sonra önce Müslüman olur. Daha sonra sünnet edilir ve büluğ yaşına kadar dini eğitim alır. Eğitim gördükleri tıbak'a yerleştirilmeden önce Türkçe bir isim alır. Tıbâk'a acemi olarak girdiğinde "ini" ismiyle sorumlu olduğu bir "ă̆a"nın kontrolünde hareket eder. Efendileri aynı kimse olup birlikte eğitim alıp sultanın ya da emirlerin hizmetine girdikten sonra da arkadaşlıkları devam eden memlûklerdir ki "hûşdâşiye" adıyla zikredilirler. Günümüzde aynı yıllarda askeri okullara ve polis kolejlerine girenlerin yanı sıra aynı yıllarda askerlik yapanların tertip-devre kelimelerini kullanmaları gibi ileride görev aldıklarında birbirlerini kollayan bu insanlar arasında grup dayanışması söz konusudur. Bir aile ortamı için gerekli kavramların ihdas edilip birbirlerine kaynaşmaları için yarışların düzenlendiği, asabiyet bağlarının aşılandığı tıbaklarda fürûsiyye yani bir süvari için gerekli askeri eğitimler verilir. Bu eğitimler ferdi olmalarının yanı sıra kabak, çevgân (top oyunu), atıcılık gibi toplu yarışlar tertip edilir. Ayrıca azat oluncaya kadar evlenmelerine izin verilmez. Çetin, a.g.e., s. 81-92.
} 
azleder ve tahta oturur. ${ }^{52}$ İrsiyete yani soy bağlılığına dayanmayan bu saltanat yapısında mevcut sultanın devlet idaresindeki yetersizliğinden ya da sultanın büyük emirleri göz ardı ederek keyfi icraatlarda bulunmasından dolayı güç kullanılarak ya da suikast tertipleyerek taht gasp edilir. Tahta oturan yeni sultan halifeden aldı̆̆ ahidnâme ile de meşru bir sultan olarak görevine başlar. Ancak yukarıda da değindiğimiz üzere teorik olarak devlette varlığını idame ettiren halifenin bu ahidnâmesi genelde güçlü ve nüfuzlu emirleri sultan olarak atamaktan öteye geçmez.

Yukarıda değindiğimiz gibi devletin saltanat yapısının oluşum süreci devletin kuruluş dönemi ile başlamıştır. Eyyûbiler devletini sona erdiren siyasi cinayetler yeni bir devletin oluşumuna imkân sağladığı gibi sonraki dönemlerde yaşanacak saltanat değişimlerine de örnek bir model olmuştur. Son Eyyûbî sultanı Turanşah'ın ve ilk Memlûk sultanı Aybek'in suikastla ölümü ${ }^{53}$ saltanat değişimi meselesi açısından önemlidir. Yine Sultan Aybek'in üst düzey emirlerden ve olası sultan adayı olan Atabek ${ }^{54}$ Farisüddin Aktay'1 idam ettirmesi saltanatın devamlılığı için bir diğer önemli gelişmedir. Sonraki dönemlerde de sultanlar Kutuz, Eşref Halil ve Lâçîn sultan iken Baydara ve Tuğçu ise sultan ilan edildikten hemen sonra suikastla öldürülmüşlerdir. ${ }^{55}$ $\mathrm{Bu}$ cinayetlerden başka ilk Memlûk sultanı Aybek'in oğlu Nureddin Ali, Sultan Baybars'ın oğulları Berke ile Sülemiş ve Sultan Kalavun'un ikinci oğlu Nâsır Muhammed yaşlarının küçüklüğü, devlet idaresindeki kifayetsizlikleri öne sürülerek azledilmişlerdir. Kutuz, Nureddin Ali'yi, ${ }^{56}$ Kalavun, Sülemiş̧'i ${ }^{57}$ Ketboğa da Nâsır Muhammed'i tahttan indirerek ${ }^{58}$ saltanat tahtına oturan kıdemli emirlerdir. Özetlemek gerekirse eceliyle vefat eden Sultan Baybars ile Sultan Kalavun haricinde tahta oturan sultanların hepsi zorla tahttan indirilmişlerdir. Bunların hepsi ya öldürülmüş ya da

52 Cüneyt Kanat, "Bahrî Memlûkler Zamanında Sultanlara ve Devlet Adamlarına Düzenlenen Bazı Suikastlar", Türk Kültürü Incelemeleri Dergisi, Sayı: 3, İstanbul 2000, s. 24.

${ }^{53}$ Kanat, a.g.m., s. 25-29.

${ }^{54}$ Atabek ya da Atabekü'l-Asâkir Memlük orduları başkumandanı olup sultandan sonra ordunun sevk ve idaresinden sorumlu olarak günümüz Genel Kurmay Başkanlığı denginde ancak dönemi itibarıyla hem siyasi hem de askeri bir mevkide söz sahibidir. Kalkaşendî, Subhu'l-A'şâ, c. IV, s. 18.

${ }^{55}$ Bahri Memlûkler zamanında yaşanan bu suikastlar için bkz. Kanat, a.g.m., s. 23-56.

${ }^{56}$ Aybek'ten sonra tahta oturtulan küçük yaştaki Nureddin Ali, Mısır kapılarına dayanmış Moğol tehlikesi öne sürülerek üst düzey devlet adamlarının istişaresi sonrası Kutuz Sultan seçilmiştir. Kutuz olası bir tehlikeyi göz önünde bulundurarak Ali'yi önce Dımaşk'a hapsettirmiş daha sonra da Bizans'a sürgüne göndermiştir. Makrizi, Sülûk, c. I, s. 417.

57 Baybars'ın devlete yaptığ hizmetler ve hatırasına hürmeten sağlığında iken veliaht tayin ettiği oğlu Berke (1277-1279) daha sonra da diğer oğlu Sülemiş (1277) tahta çıkartılmışlar ancak Sülemiş'in yaşının küçüklüğü öne sürülerek Kalavun tahta oturmuştur. Makrizi, Sülûk, c. I, s. 468.

${ }^{58}$ Ketboğa, maktül Sultan Eşref Halil'in memlûklerinin isyan ettiği günün sabahında emirlerin hepsini toplayarak makamında oturum düzenler. Emirlere hitaben; "Devletin şeref ve namusu kırıldı, saygınlı̆̆ kayboldu. Çocuk yaştaki en-Nâsır'ın sultanlı̆̆ıyla bunları să̆lamak imkânsız" dedikten sonra halifenin ve kadıların huzurunda emirlerin ittifakıyla Nâsır Muhammed'in hal edilip Ketboğa'nın Sultan olmasına karar verirler. Nüveyri, a.g.e, c. XXXI, s. 179; Makrizi, Sülûk, c. I, s. 806. 


\section{ORTAÇAĞDA ORİJINAL BİR SIYYASİ YAPI: GÜÇLÜ VE NÜFUZLU HER EMİR SULTAN OLUR}

sürgün edilmiştir. Ancak Zeyneddin Ketboğa halefi Lâçîn'e itaat ederek hayatının sonuna değin önce Serhad'de daha sonra da Hama'da nâiblik yapmıştır. ${ }^{59}$

$\mathrm{Bu}$ siyasi yapıda suikastı gerçekleştirdikten sonra tahta oturan sultanlardan bazısının aynı akıbeti paylaştığı görülmüştür. Son Eyyûbî sultanı Turanşah'a suikast tertipleyicilerden Aybek sultan olduktan sonra suikastla hayatını kaybetmiştir. Yine Sultan Aybek suikastının elebaşlarından Sultan Kutuz, Aybek'in oğlu Nureddin Ali'yi azlettikten sonra sultan olmuş ve Moğollara karşı kazandiğı Ayn-1 Câlût zaferi sonrasında daha önceki bir iç hesaplaşma sebebiyle Baybars önderliğinde tertiplenen bir suikastla yaşamını yitirmiştir. ${ }^{60}$ Yine Kalavun'un ilk oğlu Eşref Halil gücendirdiği babasının memlûkleri olan üst düzey emirler tarafından elim bir suikastla öldürülmüş ve olay yerinde sultan ilan edilen katili Baydara hemen oracıkta maktül sultanın memlûkleri tarafından intikam hırsıyla öldürülmüştür. ${ }^{61}$ Eşref Halil'in bir başka katili Lâçîn suikast sonrası önce gizlenmiş daha sonra da şartlar elverince Ketboğa'dan sonra sultan olmuştur. Ancak o da Eşref Halil'in memlûklerinden emirler Tuğcu ve Gürcû önderliğinde tertiplenen bir suikastla öldürülmüştür. ${ }^{62}$ Lâçîn suikastı sonrası emirler önce Nâsır Muhammed'in Kerek'ten çağrılıp tahta oturtulmasında anlaşmışlar ancak daha sonra Nâsır'ın yaşının küçük olduğu gerekçesiyle suikastın tertipleyicilerinden Tuğcu sultan yapılmak istenmiştir. ${ }^{63}$ Hadiseden bir gün sonra Çukurova bölgesinden seferden dönen Emir Bedreddin Bektaş'ın Kahire'ye girmesiyle hesaplar altüst olmuştur. Önce Tuğcu daha sonra da Gürcü öldürülmüştür. ${ }^{64}$ Sonrasında da Nâsır Muhammed ikinci kez tahta oturtulmuştur. Memlûk Türk Devleti'nin saltanat yapısının oluşum süreci olan bu dönemde saltanat makamının güçlü emirlere açık olması kanlı iktidar değişimlerine her zaman kapı aralamıştır.

Memlûk Türk Devleti'nde taht kavgaları için yaşanan siyasi cinayetler modern tarihçiler tarafından farklı anlayışlarla yorumlanmıştır. Cinayetlere maruz kalanlar acınarak anlatıldığ ${ }^{65}$ gibi bu tatsız olaylar sayesinde memlûk sisteminin ayakta kaldığını $^{66}$ ifade edenler de olmuştur. Hatta bu olayların dinamik bir denge oluşturduğunu ${ }^{67}$ iddia edenler de vardır. Danıel Beumont, bu bilgileri paylaştıktan sonra cinayetlerin memlûk sistemi için yararlı olduğunu söylemenin bir aldatmacadan

\footnotetext{
59 Nüveyri, a.g.e., c. XXXI, s. 202; İbn Dokmak, a.g.e., s. 99; Makrizi, Sülûk, c. I, s. 826; İbn Tağriberdi, Nücûm, c. VIII, s. 68.

${ }^{60}$ Baybars el-Mansûrî, Zübde, s. 55; Nüveyri, a.g.e., c. XXIX, s. 305-306; Kanat, a.g.m., s. 31-34.

${ }^{61}$ Makrizi, Sülûk, c. I, s. 792-793; Kanat, a.g.m., s. 38.

62 Nüveyri, a.g.e., c. XXXI, s. 226-227; Makrizi, Sülûk, c. I, s. 856-857; a. mlf., Hitat, c. II, s. 268-269; İbn Tağriberdi, Nücûm, c. VIII, s. 101-102; Kanat, a.g.m., s. 44-47.

63 İbn Devâdârî, a.g.e., c. VIII, s. 380; Nüveyri, a.g.e., c. XXXI, s. 230; Makrizi, Sülûk, c. I, s. 866.

${ }^{64}$ Nüveyri, a.g.e., c. XXXI, s. 231; Makrizi, Sülûk, c. I, s. 868-869.

65 Stanley Lane-Poole, A History of Egypt in the Middle Ages, London 1901, s. 246-247.

${ }^{66}$ Robert Irwin, The Middle East in the Middle Age, The Early Mamluk Sultanate 1250-1382, Southern Illinois University Press, 1986, s. II.

${ }^{67}$ Winslow Williams Clifford, State Formation end the structure of Politics in Mamluk Syro-Egypt, 648-741 A. H. /1250-1340 C. E. , Bonn 2013, s. 4.
} 
ibaret olduğunu belirtir ve bunların çok aşırıya kaçan şiddet eğilimleri olduğunu vurgular. ${ }^{68}$ Memlûk saltanatı için yapılan bu yorumlar tarihçilik anlayışının zamanla değişmesine paralel bir durum arz eder. ${ }^{69}$ Yine bu cinayetlerle ilgili olarak Sir Jean Glubb, Memlûk vahşetinin korkunç olduğunu ifade ettikten sonra bir hatırlatmada bulunarak bu dönemden üç yüz yıl sonra Batı Avrupa'da insanlar hâlâ çivilenerek ve yakılarak cezalandırılmaktadır, ${ }^{70}$ diyerek okuyucusunu farklı düşünmeye sevk etmektedir. Özetle saltanat mücadelesinde yaşanan bu elim hadiseler her dönemde yaşanmış doğasında var olan iktidar mücadeleleridir.

MemlUk Türk Devleti'nde saltanat yapısıyla alakalı yukarıda sunduğumuz bilgiler bağlamında saltanat tahtına üç meşruiyetten biri ile oturulduğu görülür. Birincisi veraset, ikincisi "sultanı öldüren kim ise sultan o'dur"71 darb-1 meseli ve sonuncusu "güçlü olan sultan olur" anlayışıdır. Yine tahta oturduktan sonra iradelerine göre de bu dönemdeki sultanları gerçek sultanlar ve kukla sultanlar şeklinde iki kısımda ele almak mümkündür. Aybek, Kutuz, Baybars, Kalavun, Eşref Halil, Ketboğa ve Lâçîn gibi gerçek anlamda sultan olanlar ile Aybek'in oğlu Nureddin Ali, Baybars'ın oğlu Berke ve Sülemiş ile birinci ve ikinci saltanat dönemlerinde Kalavun'un oğlu Nâsır Muhammed iradelerinin dışındaki otoritelerin devleti yönettiği kukla sultanlardır. Saltanat makamı için yaşanan siyasi cinayetler ve aziller göstermektedir ki aslında tahta oturmak için tek bir meşruiyet gereklidir; "Güç ve nüfuz sahibi kim ise sultan da o'dur". Özetle tahta oturmak için güçlü ve nüfuzlu olmak sultanın en önemli vasfıdır.

Memlûk saltanat yapısının oluşum sürecine baktığımızda hanedan oluşumuna çaba gösterilmiş ancak bu girişimler başarılı olmamıştır. Memlûkler üzerine yaptığı çalışmalarıyla tanınan K. Yaşar Kopraman, Memlûk Türk Devleti'nde Kalavun'dan sonra iki oğlu ile torunlarının bir asır boyunca (1279-1382) iktidarda kalmalarının tesadüf olduğunu ve bu durumun dönemin şartları gereği gelişen olaylar sonrası Mısır' da sultan oldukları şeklinde ifade etmiştir.72 Görüldügüu gibi Memlûk geleneği ile bağdaşmayan soy bağlılığına ya da verasete dayanmayan saltanat yapısı güçlü olanın

\footnotetext{
${ }^{68}$ Beaumont, Danıel, "Political Violence and Ideology in Mamluk Society", Mamlūk Studies Review, VIII-12004, s. 202-225, s. 202.

${ }^{69}$ Levanoni, "The Mamluk Conception of The Sultanate", s. 373.

70 Sir John, Glubb, Soldiers of Fortune The Story of The Mamlukes, Newyork, 1973, s. 157. Ayrica 2 Mart 1725'de Paris'te kralı (babasını) öldürme suçundan yargılanan Damiens'in türlü işkenceler altında acı çektirilerek mahkûmun acısını adeta keyifle seyretme seromonisine dönüşen cezalandırma teknikleri için bkz. Cüneyt Kanat, Ortaçă̆ Türk Devletlerinde Suç ve Ceza, İstanbul 2010, s. 15-17.

${ }^{71}$ Ulrich Haarmann, "Regicide and the 'Law of the Turks, '", Intellectual Studıes on Islam, ed. Michel M. Mazzaoui and Vera B. Moreen (Salt Lake City, 1990), s. 127-135; Daniel Beaumont, a.g.t., s. 218. Eski bir Türk yasası olduğu ileri sürülen bu görüşe örnek Mete'nin babası Teoman ile mücadelesidir. Mete ile Teoman'ın mücadelesini Türk mitolojisi soyluluk meselesine bağlar. Mete'nin, Teoman'ın soylu hatunundan doğan oğlu olmasına ve tahta geçecek güç ve yeteneği taşımasına rağmen, Teoman (Tuman), yeterince soylu olmayan hanımı Yensih'ten olan küçük oğlunu tahta geçirmeye çalışmış ve Mete, babasına bu yüzden savaş açmıştır. Sonuçta babasını öldüren Mete hakan olarak devleti idare etmiştir. Bahaeddin Ögel, Türk Mitolojisi, Ankara 1998, s. 6-8.

72 Kopraman, "Misır Memlûkleri”, s. 107.
} 


\section{ORTAÇAĞDA ORİJINAL BİR SIYYASİ YAPI: GÜÇLÜ VE NÜFUZLU HER EMİR SULTAN OLUR}

sultan olduğu (gücünü hûşdaşlarından ve memlûklerinden alan) askeri oligarşik bir devlet anlayışının ${ }^{73}$ egemen olduğu bir saltanat yapısı söz konusudur. ${ }^{74}$ Sultanın otokrat kişiliğiyle bağlantılı olarak monarşik bir idareyi andırsa da aslında Memlûk sultanının tahtını koruması hûşdâşlarının ve memlûklerinin gücüyle var olduğundan uygulama olarak oligarşik idari bir yapıyı andırmaktadır. Kaldı ki, merkezi ve hareketli bir bölgede devletin istikrarı her açıdan güçlü bir sultanın kanatları altında ancak mümkün olabilmiştir.

\section{Memlûk Türk Devleti'nde Saltanatın Meşruiyet Esasları}

Siyasi cinayetler ya da aziller iktidarı tayin etmek hususnda önemlidir. Ancak tahta oturan sultanın tahtı gasp etmesindeki gerekçesi kadar olası sultan adaylarına firsat vermemesi iktidarının devamlılığı için bazı meşruiyet esaslarına da haiz olması gerekmektedir. Ortaçağ Türk-İslam devletlerinde tahta oturan sultanın Allah'ın takdiri ile tahta oturduğuna dair inanç ${ }^{75}$ Memlûk Türk devletinde de değişmez. Türk devlet felsefesinde sultan olmak için ileri sürülen "Tanrı bağışı" yani "Tanrı tarafından kendisine verilen kut (devlet, baht, iyi, talih)'tan dolayı hükümdarın hâkimiyet sağladı̆̆ inanc1 $^{76}$ bu dönemde de meşruiyetini korumuştur. Sultanı hutbenin, kalemin ve kılıcın sahibi diyerek tarif eden Memlûk müelliflerinden Halil b. Şahin (ö. 873/1468), saltanatın ilâhî kaynaklı olduğunu, sultanın Allah tarafından seçildiğini ve sultanın tebaasını yönetmekle görevli bulunduğunu ifade eder. Ve yine halifelikte var olan inanc1 tekrarlayarak sultanın Allah'ın halifesi ve gölgesi olduğuna işaret eder. ${ }^{77}$ Sultanın vasıflarıyla alakalı olarak aynı müellif her şeyden önce iyi bir Müslüman olarak Allah’a itaat etmesi gerektiğini, böylece halkının da kendisine itaat edeceğini vurgular. Esas vazifesi ülkesini ve dinini korumak olan sultana karşı halkın da görevinin onu sevmek

\footnotetext{
${ }^{73}$ Levanoni, "The Mamluk Conception of The Sultanate", s. 374.

${ }^{74}$ Oligarşik idari yapıya bir diğer örnek halef-selef sultanlar arasında ve sultanlar ile emirleri arasında evlilikler yoluyla akrabalıkların tesis edilmesidir. Şüphesiz Memlûk Türk Devleti'nde halef selef ilişkilerinde dikkat çeken ögelerden birisi siyasi evlilikledir. Altın Orda Hanı Berke Han'ın kızı ile evlenen Baybars devletlerarası yaptığı bu siyasi evliliği üst düzey emirleri arasında da yapmıştır. Baybars ve Kalavun'un bacanak oldukları bir durum da bu dönemde Memlûklere iltica eden bir grup Vâfidiye'nin lideri Karamun Ağa'nın kızlarıyla her ikisinin evliliğidir. Kalavun'un çok sevdiği oğlu Ali'nin annesi olan ve ismi kaynaklarda zikredilmeyen ilk eşi ile 664 Muharrem (1265 Kasım) ayında yaptığı görkemli düğünün bütün masrafını aynı zamanda hûşdâşı olan Sultan Baybars karşılamıştır. (Baybars el-Mansûrî, Tuhfe, s. 56; Makrizi, Sülûk, c. I, s. 542.)Karamun'un diğer kızıyla da Baybars'ın kendisinin evlendiği görülmektedir. (Baybars el-Mansûrî, Tuhfe, s. 56.) Sultan Baybars ile Kalavun'un akrabalık ilişkileri Baybars'ın oğlu Berke ile Kalavun'un kızı Gaziye'nin 674/1276 yılındaki evliliği ile daha da ilerlemiştir. Baybars el-Mansûrî, Tuhfe, s. 83; Makrizi, Sülûk, c. I, s. 623.

75 “De ki: "Mülkün sahibi olan Allah'ım! Mülkü dilediğine verirsin; dilediğinden çekip alırsın; dilediğini aziz kılar, dilediğini alçaltırsın; iyilik elindedir. Doğrusu Sen, her şeye kadir'sin"'”. Kur'an-1 Kerim, 3:26.

${ }^{76}$ Osman Turan, Türk Cihan Hâkimiyeti Mefküresi Tarihi, İstanbul 2006, s. 113-116; Kafesoğlu, a.g.e., s. 355370; Ali Aktan, "Memlüklerde Saltanat Değişikliği Usulü", Atatürk Üniversitesi İlahiyat Fakültesi Dergisi, Sayı 9, Erzurum 1990, s. 270.

77 Halil b. Şahin, a.g.e., s. 53-67; Süleyman Özbek, “Zübdetü'l-Keşfi'l-Memâlîk'de Türk Devlet Telâkkisinin Yansımaları", GEFAD, Cilt, 29, (Prof. Dr. Reşat Genç'e Armağan sayısı), s. 82-94.
} 
ve ona itaat etmektir diye özetler. ${ }^{78}$ Yine bu bağlamda Makrizi, iki kısma ayırdığ 1 Ahkâmü's-Siyâsiyye (siyasi kararlar)'yi Memlûk Türk Devleti'nde şerî ve siyasî olarak iki başlık altında ele alır. Şerî kısmı iyi bir Müslüman olmak diye özetledikten sonra siyasî ahkâmı da adaletle yönetim diyerek ifade eder. ${ }^{79}$ Nüveyri'nin uzun malumatlarla anlattığı sultanın vasıfları ${ }^{80}$ hakkında en önemli husus şüphesiz adalettir. ${ }^{81}$ Çalışma dönemimizin çağdaşı olup Kalavun'un memlûklerinden Türk kökenli müellif Baybars el-Mansûrî bu durumu Nâsır Muhammed ile özdeşleştirerek sultanın yerli yabancı herkese adil davranması sonucu ülkenin refah düzeyinin arttığına değinmiştir. ${ }^{82} \mathrm{Bu}$ çerçevede Memlûk Türk Devleti'nde adalet konusu bizzat sultanların iştirakiyle tertip edilen mezâlim divanlarında temayüz etmiştir. Dîvanü'l-Mezâlim, devlette söz sahibi emirlerin ve memurların adaletsiz ve hukuk dişı uygulamalarına engel olmak için sultanın bizzat iştirakiyle özel olarak tertip edilen yüksek mahkemelerdir. Memlûk Türk Devleti'nde Aybek et-Türkmani es-Sâlihiyye Medresesi'nde, Sultan Baybars da Kal'atü'l-Cebel'de inşa ettirdiği Dâru'l-Adl'de mezâlim duruşmaları düzenlemiştir. Daha sonra Nâsır Muhammed üçüncü saltanat döneminde başta Kahire olmak üzere Mısır coğrafyasını yeniden inşa ettiği gibi bu binayı yıktırarak daha büyük ve geniş Eyvanlı ayrı bir daire inşa ettirerek burada şikâyetleri dinlemiştir. Nâsır Muhammed Ramazan ayı dışında haftada iki kez Pazartesi ve Perşembe günleri burada mezâlim divanı akdetmiştir. ${ }^{83}$

\footnotetext{
${ }^{78}$ Halil b. Şahin, a.g.e., s. 49. Baydara'nın Eşref Halil'e karşı düzenlediği suikastın gerekçesi sultanın kişisel zafiyetlerinin yanında iyi bir Müslüman olmaması iddiasıdır. Makrizi, Sülûk, c. I, s. 792-793. Kaynaklar bu konuda çok açık olmasa da Baydara'yı askeri başarılarıyla öne çıkan bir fatihe karşı suikast tertip etmeye iten gerekçe Makrizi'nin kayıtları olsa gerek. Makrizi, Eşref Halil'in katillerinden Baydara'nın cebinden "Ramazan'da şarap içen, fasıklık yapan, namaz kılmayan kimsenin katledilmesi hususunda fukahanın görüşü nedir? Cevap olarak da, öldürülür ve katiline günah olmaz" yazılı pusulanın çıktığını haber verir. Makrizi, Sülûk, c. I, s. 792-793. Yine Nâsır Muhammed oğlu Anuk'un uygunsuz davranışlarını öğrendiğinde üstâdâr Akboğa'yı görevlendirerek, kendisinin haberi yokmuş gibi davranıp oğlunun birlikte vakit geçirdiği şarkıcı kadınları cezalandırmasını emreder Makrizi, Sülûk, c. II, s. 491-492; Fatih Yahya Ayaz, Türk Memlûkler Döneminde Saray Ağalığı: Üstâdârlık (1250-1382), Marmara Üniversitesi İlahiyat Fakültesi Vakfı Yay., İstanbul 2008, s. 112.

${ }^{79}$ Makrizi, Hitat, c. II, s. 220.

${ }^{80}$ Nüveyri, a.g.e., c. VI, s. 5-86.

${ }^{81}$ Bilindiği gibi, doğulu devletler için söylenmiş bir darb-ı mesel vardır: “Sultanın devletini koruması için orduya ihtiyaç vardır. Ordunun ayakta kalması için paraya mala ihtiyaç vardır. Gerekli paranın temin edilmesi için de halka ihtiyaç vardır. Halktan düzenli olarak paranın yani verginin tahsili için de adil bir vergi sistemine ihtiyaç vardır. Kısaca adalet mülkün yani devletin temelidir". Koçi Bey Risalesi, (Sad. Zuhuri Danışman), Milli Eğitim Bak. Yay. İstanbul 1993, s. 36.

82 Müellif bir Türk töresi olan şu sözlerle adaletin önemine değinmiştir “Dünya devlet çitleri ile çevrili bir bahçedir. Devleti yöneten sultandır. Sultan, askeri ile ayakta duran bir çobandır. Asker ise mal ile ayakta duran ordudur. Mal tebaadan toplanan bir rızıktır. Tebaa ise adalet ile yaşayan halktır. Adalet dünyayı ayakta tutar" dedikten sonra Baybars el-Mansûrî sözlerini şöyle tamamlar "İste efendimiz Sultan Nâsır Muhammed bütün bu özellikleri kendisinde topladı. Bu sebeple de Allah kendisi ve halkı için daha önceki hiçbir melike nasip etmediğ $i$ kadar geniş nimetler ihsan etti". Baybars el-Mansûrî, Tuhfe, s. 222.

${ }^{83}$ Mezâlim divanı hakkında bkz. Ömerî, Mesâlik, c. III, s. 292-293; Kalkaşendî, a.g.e., c. IV, s. 44-45; Nüveyri, a.g.e., c. XXXII, s. 133-134; Makrizi, a.g.e., c. II, s. 207-209. Nâsır Muhammed b. Kalavun'un Dâru'l-Adl'de
} 


\section{ORTAÇAĞDA ORİJINAL BİR SIYYASİ YAPI: GÜÇLÜ VE NÜFUZLU HER EMİR SULTAN OLUR}

Sultanların devlete hükmetmeleri güçlü ve nüfuzlu oldukları kadar uzun süre tahtta kalmaları da adil bir yönetim sergilemeleriyle mümkün olmuştur. Başta iyi bir Müslüman olması gereken sultanın sorumluluk bilinciyle hareket edip halkını gözetmesi zulme maruz kalanların şikâyetlerini dinleyip hakkaniyet çerçevesinde hareket etmesi saltanatının meşruluğu açısından önemlidir. P. M. Holt, konuyla alakalı otokrat bir yapısı olan sultan hakkında ne tam bağımsız ne de mutlak devlete hâkimdir, dedikten sonra Müslüman olarak sorumluluklarının yanında kadılar sultanın her yaptığını da sorgulayamaz ${ }^{84}$ şeklinde sultanın konumunu özetler. Ancak son olarak şunu belirtelim ki güçlü ve nüfuzlu olan sultanın saltanatını idame ettirebilmesi için her alanda açık vermemesi gerekir. Zaafını ileri sürerek tahtına göz dikecek olan en yakın adamlarının varlığı Memlûk saltanat yapısının en önemli özelliğidir.

\section{Sonuç}

Memlûk Türk Devleti Haçlı işgalleri ve Moğol istilâlarının ortaya çıkardığı bir Türkİslam devletidir. Ortaçağ Türk-İslam devletlerinden farklı olarak en önemli özelliği bir hanedan tarafından yönetilmeyip güçlü ve nüfuzlu her emire saltanat yolunun açık olmasıdır. Zaman zaman seleften halefe taht değişimi irsiyete bağlı olarak gerçekleşse de güçlü ve nüfuzlu bir emir genç sultanı azlederek her defasında tahta oturmuştur. Bu durum ilk dönemlerde bölgenin siyasi buhranının bir neticesi olsa da zamanla bu durum geleneğe dönüşür. Yine bazı sultanlar babalarından sonra tahta otursalar da bu sultanlar güçleri ve nüfuzları karşılığında tahtta uzun süre kalma becerisi gösterebilmişlerdir. Örneğin Sultan Nâsır Muhammed üç kez tahta oturmuştur. Birinci ve ikinci saltanat dönemleri kukla olarak devlette söz sahibi emirlerin iktidarına meşruiyet kazandırmaktan öteye geçmemiştir. Ancak üçüncü kez kendi memlûk oligarşisini tesis etmeyi başarmış güçlü ve nüfuzlu bir sultan olarak uzun bir süre tahtta oturmuştur. Babası sultan ola da 30 yılı aşan parlak bir dönemi kendi becerisi ve gücü sayesinde inşa etmiştir.

Moğol istilâları hanedanlar idaresindeki Harzemşahlar, Abbasiler, Eyyûbiler ve Anadolu Selçuklu devletlerini ortadan kaldırırken Memlûk Türk Devleti'nin siyaset sahnesine çıkmasını sağlamıştır. Yine Haçlıları ve Moğolları Türk-İslam coğrafyasından uzaklaştırmayı başaran tek siyasi yapı da Memlûk Türk Devleti olmuştur.

tertip ettiği mezâlim divanları için bkz. Nüveyri, a.g.e., c. XXXII, s. 133-134; İbn Battûta, Ebû Abdullah Muhammed b. Abdullah b. Muhammed b. İbrahim Levatî et-Tancî (ö. 770/1368), İbn Battûta Seyahatnâmesî, I-II, (Çev. A. Sait Aykut), Yapı Kredi Yay., İstanbul 2000, c. I, s. 55-56.

${ }^{84}$ P. M. Holt, a.g.m., s. 227. 


\section{KAYNAKÇA}

Aktan, Ali, "Memlüklerde Saltanat Değişikliği Usulü", Atatürk Üniversitesi İlahiyat Fakültesi Dergisi, Say1 9, Erzurum 1990, s. 270-279.

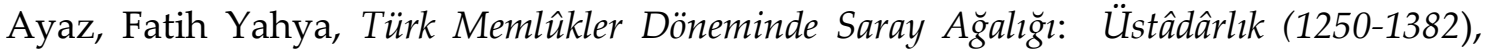
Marmara Üniversitesi İlahiyat Fakültesi Vakfı Yay., İstanbul 2008.

Aycan, İrfan "Saltanata Giden Yolda Muaviye b. Ebî Süfyan”, İslâmî Araştırmalar Dergisi, Cilt:4; S:2, Nisan 1990, ss. 130-145.

Baybars el-Mansûrî (ö.725/1325), et-Tuhfetü'l-Mülûkiyye fi'd-Devleti't-Türkiyye (Thk. Abdülhamid Salih Hamdân), Kahire 1987.

; Zübdetü'l-Fikre fî Târîhi'l-Hicre (Thk. D. S. Richards), Beyrut Das Arabische Buch Berlin, 1998/1419.

Beaumont, Daniel, "Political Violence and Ideology in Mamluk Society", Mamlūk Studies Review, VIII-1-2004, s. 202-225.

Clifford, Winslow Williams, State Formation end the Structure of Politics in Mamluk SyroEgypt, 648-741 A. H. /1250-1340 C. E. , Bonn 2013.

Çetin, Altan,, Memlük Devletinde Askeri Teşkilat, Eren Yayıncılık, İstanbul 2007, s. 48-52.

Develioğlu, Ferit, Osmanlıca-Türkçe Ansiklopedik Lûgat, Ankara 2006.

Elçibey, Ebülfez, Tolunoğulları (868-905), (Haz. Fazil Gezenferoğlu), İstanbul 1997.

Eymen, Fuad Seyyid, "Makrizî”, DİA, Ankara 2003, c. XXVII, s. 448-451.

Halil b. Şahin ez-Zahiri (ö. 873/1468), Zübdetü Keşfi'l-Memâlik fi Beyanii't-Turuk ve'lMesâlik, (Thk. Halil Mansur), Beyrut 1997/1417.

Holt, P. M., "Memlük Sultanlığında Devlet Yapısı”, (Ter. Samira Kontantamer), Belleten LII/202, 1988, s. 227-246.

Glubb, Sir John, Soldiers of Fortune The Story of The Mamlukes, Newyork, 1973.

İbn Battûta, Ebû Abdullah Muhammed b. Abdullah b. Muhammed b. İbrahim Levatî et-Tancî (ö. 770/1368), İbn Battûta Seyahatnâmesî, I-II, (Çev. A. Sait Aykut), Yapı Kredi Yay., İstanbul 2000.

İbn Habib (ö.1377), Dürretü'l-Eslâk fi Devleti'l-Etrâk, Süleymaniye Ktp. Yeni Cami, $\mathrm{Nr}: 849$.

İbn Devâdârî, Ebû Bekr b. Abdullah b. Aybek İbnü'd-Devadari (ö. 736/1336), Kenzü'dDürer ve Câmiü'l-Gurer I-IX, (Thk. Ulrich Haarmann), Kahire 1971.

İbn Dokmak (ö.1407), en-Nüfhatü'l-Miskiyye fî́d-Devleti't-Türkiyye: min Kitâbi'lCevheri's-Semin fî Siyeri'l-Hulefâ ve'l-Mülûk ve's-Selâtîn (min sene 637 hatta sene 805 h.), (Thk. Ömer Abdüsselam Tedmuri), Beyrut 1999/1420. 


\section{ORTAÇAĞDA ORİJINAL BİR SIYYASİ YAPI: GÜÇLÜ VE NÜFUZLU HER EMİR SULTAN OLUR}

İbn Kesir, Ebü'l-Fidâ İmadüddin İsmail b. Şihabüddîn Ömer b. Kesîr b. Dav' b. Kesir (ö. 774/1373), el-Bidâye ve'n-Nihâye, I-XXI, (Thk. Abdullah b. Abdülmuhsin et-Türkî), Cîze 1998/1419.

İbn Haldun, Ebu Zeyd Veliyyüddin Abdurrahman b. Muhammed İbn Haldun (ö. 808/1406), Kitâbü'l-İber ve Dîvanü'l-Mübtedâ ve'l-Haber fì Eyyâmi'l-Arab ve'l-Berber ve men Asserehüm min zevi's-Sultâni'l-Ekber, I-VIII, (Thk. Halil Şehhâde), Beyrut $1421 / 2001$.

; Mukaddime, I-III, (Ter. Zakir Kadiri Ugan) MEB Yay. İstanbul 1991.

İbnü'l-Esir, El Kâmil Fi't-Tarih Tercümesi, c. XII, Bahar Yayınları, İstanbul 1985.

İbn İyas, Ebü'l-Berekat Zeynüddin Muhammed b. Ahmed İbn İyas (ö.930/1520), Bedâiu'z-Zuhûr, fî Vekâi'u'd-Dühûr, I-V, (Thk. Muhammed Mustafa), Kahire 1395/1975.

İbn Tağriberdi, Ebü'l-Mehasin Cemalüddin Yusuf İbn Tağriberdi (ö. 874/1470), enNücûmü'z-Zâhire fî Mülûki Misr ve'l-Kahire, I-XVI, (Thk. Muhammed Hüseyn Şemseddin), Dâru'l-Kütübi'l-İlmiye, Beyrut 1992/1413, c. IX, s. 127-128.

; el-Menhelü's-Sâfî ve'l-Müstevfî ba'de'l-Vâfî̀, I-XIII, (Thk. M. Muhammed Emin, Said Abdülfettah Âşûr), Kahire 1984/1405.

Kanat, Cüneyt, "Bahrî Memlûkler Zamanında Sultanlara ve Devlet Adamlarına Düzenlenen Bazı Suikastlar", Türk Kültürü İncelemeleri Dergisi, Sayı: 3, İstanbul 2000, s. 23-56.

; Ortaçă̆ Türk Devletlerinde Suç ve Ceza, Küre Yayınları, İstanbul 2010.

Kafesoğlu, İbrahim, Türk Milli Kültürü, Ötügen Neşriyat, İstanbul 2006.

Kalkaşendî, Ebü'l-Abbas Şihabüddin Ahmed b. Ali Kalkaşendî (ö. 821/1418), esSubhu'l-A'şâ fî Sinâati'l-İnşâ, I-XIV, (Thk.

Kızıltoprak, Süleyman, "Memlûk Sistemi”, Türkler, Ankara 2002, c. V, s. 322-323.

Kopraman, K. Yaşar, “Tolunoğulları”, DGBİT, İstanbul 1992, c. VI, s. 55-81. ; “İhşidiler”, DGBİT, İstanbul 1992, c. VI, s. 194-206.

; “Misır Memlükleri", DGBİT, İstanbul 1992, c. VI, s. 433-540.

Koçi Bey Risalesi, (Sad. Zuhuri Danışman), Milli Eğitim Bak. Yay. İstanbul 1993.

Kortantamer, Samira, “Memlüklerde Devlet Yönetimi ve Bürokrasi” TíD 1984, 27-45.

Levanoni, Amalia, "The Mamluk Conception of The Sultanate”, International Journal of Middle East Studies, Vol. 26, No. 3 (Aug. , 1994), pp. 373-394.

; "The Mamluks in Egypt and Syria: the Turkish Mamluk sultanate (648784/1250-1382) and the Circassian Mamluk sultanate (784 923/1382 1517)" The New 
Cambridge History of Islam: The Western Islamic World Eleventh to Eighteenth Centuries, Edited By Marıbel Fierro, Vol. II, pp. 237-285.

Makrizi (ö.1442), Makrizi, Ebü'l-Abbas Takıyyüddin Ahmed b. Ali b. Abdülkadir Makrizi (ö. 845/1442), Kitabü'l-Mevâiz ve'l-İtibâr fi Zikri'l-Hıtat ve'l-Âsâr, III, Beyrut t. y. Dâru Sâdır.

; Kitâbü's-Sülûk li-Ma'rifeti Düveli'l-Mülûk, I-IV, (Thk. Muhammed Mustafa Ziyade-Said Abdülfettah Âşûr), Kahire 1934, 1958,

Muhammed Hamidullah, “Abd”, DİA, c. I, İstanbul 1988, s. 57.

Nüveyri, Ebu'l-Abbas Şihabüddîn Ahmed b. Abdülvehhâb b. Muhammed el-Bekrî etTeymî el-Kureşî en-Nüveyri (ö.733/1333), Nihâyetü'l-Ereb fî Fünûni'l-Edeb, I-XXXI (Thk. Dr. Necip Mustafa Fevvaz, Dr. Hikmet Keşlî Fevvaz), Beyrut 2004.

Ögel, Bahaeddin, Türk Mitolojisi, Türk Tarih Kurumu Yay., Ankara 1998.

Ömerî, Ebü'l-Abbas Şehabeddin Ahmed b. Yahyâ İbn Fazlullah el-Ömerî (ö. 749/1349), Mesâlikü'l-Ebsâr fî Memâliki'l-Emsâr, I-XXVII, (Thk. Kamil Selman el-Cebûrî), Beyrut 2010.

; et-Ta'rîf bi'l-Mustalahi'ş-Şerîf (Thk. Semîr Mahmûd Derubi), Kerek 1992/1413.

Özbek, Süleyman, “Zübdetü'l-Keşfi'l-Memâlîk'de Türk Devlet Telâkkisinin Yansımaları", GEFAD, Cilt, 29, (Prof. Dr. Reşat Genç'e Armağan sayısı), s. 82-94.

;“El-Melikü'z-Zahir Rüknü'd-Din Baybars Zamanı Dini Siyaseti”, TíD, Sayı: IX, (1994), s. 289-307.

Özdemir, Mehmet Nadir, “Abbasi Halifesi Mu'tasım'ın Ordusunda Bulunan Türklerin "Köle" Olup Olmadığı Meselesi", Selçuk Üniversitesi, Türkiyat Araştırmaları Dergisi, Say1:18, (2005), s. 211-230.

Özkuyumcu, Nadir, “Tolunoğulları”, Türkler, Ankara 2002, c. V, s. 15-38.

; “İhşîdiler”, Türkler, Ankara 2002, c. V, s. 39-59.

; “Kelb”, DIA, c. XXV, Ankara 2002, s. 203-204.

Safedî, Salahaddin Halil bin İzzeddin Aybek es-Safedî (ö. 762/1363), A'yânü'l-Asr ve A'vânü'n-Nasr, (Thk. Ali Ebû Zeyd, Mahmûd Salim Muhammed, Nebil Ebû Amse, Muhammed Mev'1d), I-VI, Dimaşk 1998/1418.

Steenbergen, J. Van, “The Amir Qawsun: Statesman or Courtier? (720-741 AH/13201341 AD)" In Egypt and Syria in the Fatımid, Ayyubid and Mamluk Eras, III, ED. U. Vermeulen and J. Van Steenbergen, 2001, pp. 449-466. 


\section{ORTAÇAĞDA ORİJINAL BİR SIYYASİ YAPI: GÜÇLÜ VE NÜFUZLU HER EMİR SULTAN OLUR}

Süyûtî, Ebü'l-Fazl Celaleddin Abdurrahman b. Ebi Bekr b. Muhammed el-Hudeyrî esSüyûtî (ö. 911/1505), Târîhu'l-Hulefâ, (Thk. Muhammed Muhyiddin Abdülhamid), Kahire 1964.

Şeşen, Ramazan, El-Cahiz ve Türklerin Faziletleri, İstanbul 2002.

Sürûrî, M. Cemaleddin, Devletü Beni Kalavun, Kahire 1947.

Stanley Lane-Poole, A History of Egypt in the Middle Ages, London 1901, s. 246-247.

Robert Irwin, The Middle East in the Middle Age, The Early Mamluk Sultanate 1250-1382, Southern Illinois University Press, 1986.

Turan, Osman, Selçuklular Zamanında Türkiye, Boğaziçi Yayınları, İstanbul 1996.

Ulrich Haarmann, "Regicide and the 'Law of the Turks, '", Intellectual Studies on Islam, ed. Michel M. Mazzaoui and Vera B. Moreen (Salt Lake City, 1990), s. 127-135.

Yıldız, H. Dursun, “Türklerin Müslüman Olmalar1”, Doğuştan Günümüze Büyük İslam Tarihi, İstanbul 1992, c. VI, s. 17-27.

; “İlk Dönem Abbasi Halifeleri”, DGBİT, İstanbul 1992, c. III, s. 64-69.

; “Bermekiler”, DİA, c. V, İstanbul 1992, s.517-520.

; İslamiyet ve Türkler, İstanbul 2000.

İsmail Yiğit, “Kutuz”, DİA, c. XXVI, Ank 